
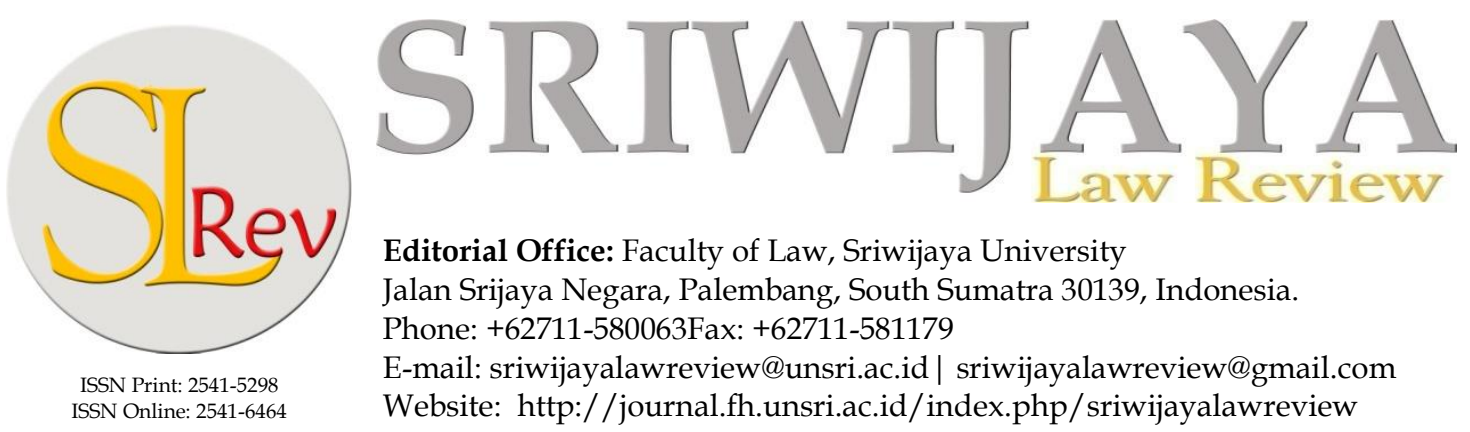

Editorial Office: Faculty of Law, Sriwijaya University

Jalan Srijaya Negara, Palembang, South Sumatra 30139, Indonesia.

Phone: +62711-580063Fax: +62711-581179

E-mail: sriwijayalawreview@unsri.ac.id | sriwijayalawreview@gmail.com

Website: http://journal.fh.unsri.ac.id/index.php/sriwijayalawreview

\title{
TRADE LIBERALIZATION AND CONSUMER VULNERABILITY: A LEGAL FRAMEWORK ON LEGISLATIONS AND TESTING MECHANISM FOR ASEAN PRODUCT SAFETY DIRECTIVE
}

\author{
Syed Sagoff Alsagoff ${ }^{1}$ and Rahmah Ismail ${ }^{2}$
}

\begin{abstract}
Since its inception in 1967 ASEAN has advanced in great leaps in the economic sector luring new member states into its pact. From a mere five member states (Malaysia, Indonesia, Thailand, Singapore and the Philippines) ASEAN has today managed to entice five other neighbouring states (Brunei 1984, Vietnam 1995, Laos \& Myanmar 1997, Cambodia 1999) into its pact transforming itself into union of ten member states with a consumer population expected to exceed 600 million people. In order to ensure sustainability amid global challenges, member states have engrossed ASEAN Charter in 2007 with a view of creating an ASEAN Economic Community by 2015 that is robust, competitive and sustainable. At this juncture, ASEAN has to realize that like any trade liberalization initiatives, goods moved readily and freely throughout the free-trade area that is facilitated by a lucrative non-barrier tariffs incentives. This vision of a single market which creates a frontier without borders can prove to be advantageous to member states only if they have the required vehicle that is able to overcome the drawback of its progression through harmonization and synchronization efforts that is effective and successful. Like everything else, every advantage has some disadvantages attached to it. This article will address important determining factors that are crucial in the development and scope of proposed ASEAN Product Safety Directive including reviewing relevant determining factors such as regional stability, consumer protection legislations and standard and testing agencies of which one without the other will be incomplete. The proposals suggested in this article will strengthen and unite ASEAN in overcoming unsafe product issues at ASEAN level.
\end{abstract}

Keywords: ASEAN Economic Community; ASEAN Product Safety Directive; consumer protection; trade liberalization; unsafe product issues.

\section{ARTICLE HISTORY:}

Received:

Dec 30, 2016; Reviewed: Jan 6, 2017

Accepted:

Jan 13, 2017; Published: Jan 30, 2017

${ }^{1}$ Senior Officer, Standards and Conformance Trade Facilitation Division, Market Integration Directorate, ASEAN Economic Community

Department, ASEAN Secretariat

\footnotetext{
${ }^{2}$ Faculty of Law, University Kebangsaan Malaysia, 43600 UKM Bangi, Selangor, Malaysia

Emailirahmah@ukm.edu.my
}

\section{INTRODUCTION}

Unlike ASEAN, the European Union has the required vehicle and essential mechanics in ensuring consumer are afforded with the state of the art consumer protection regime 
across its union through the harmonization of its product safety mechanism which is already in place. Similarly, the issue of product safety continuously takes centre stage and are still under an on-going process of development and refinement within the European Union.

In the recent annual report published by RAPEX in 2010, it reported that the number of notifications concerning product safety is on the rise from the previous 1993 in 2009 to 2244 in 2010 which signify an increase of almost $13 \%^{1}$ from the previous year. The alarming issue is that despite the various mechanisms in place the number of notifications which falls under the category of serious risks amounted to 1963 notifications. According to RAPEX Annual Report out of some 2244 notifications which were raised, products manufactured and originated from China (including Hong Kong) accounted to almost 1134 notifications or almost $58 \%$ of all reported notifications.

In light of the above statistics ASEAN in its trade liberalization and sustainability program should be more vigilant in protecting its consumers since China is its major trading partner coupled with the fact that ASEAN lacks the infrastructure to monitor goods coming from China or anywhere as the case maybe. The mere fact that each ASEAN state has differing consumer protection laws and safety standards will without doubt succumb its consumers to vulnerability in the midst of benefitting from its trade liberalization and economic sustainability program. The fact that

RAPEX Annual Report 2010, Keeping European Consumer Safe, Luxembourg Office for Official Publications of the European Communities 2011.
ASEAN is slow in its progression (as compared to the European Union despite a mere ten years gap between the signing of the Treaty of Rome and the ASEAN Declaration) may prove major and on-going set-back for ASEAN it fails to swiftly narrow the gap that exist presently through synchronization and harmonization of its safety standards and policy that uphold consumer protection within the region.

\section{ANALYSIS AND DISCUSSION}

\section{Regional Cooperation and Stability}

The focus and vision towards regional cooperation and the establishment of the Association of Southeast Asia Nations (ASEAN) started as early as 1961. With the need for political independence and regional cooperation amid the detachment from their once colonial masters resulted with the initial formation of Association of Southeast Asia $(\mathrm{ASA})^{2}$ which comprises of regional countries like Thailand, Malaysia and Philippines. Unfortunately the issues of territorial disputes over North Borneo (Sabah) resulted in strained relations between Indonesia, Philippines and Malaysia which subsequently lead to the first failed attempt in its cooperation.

The second phase started again in 1963 with the cooperation between Malaysia, Indonesia and Philippines under the umbrella of MAPHILINDO ${ }^{3}$ which was manifested on the pretext to unite the Malays and to do away with political upheaval. This time round the issues of territorial disputes over Sabah again took centre stage which subse-

\footnotetext{
2 Consumers International Asia Pacific 2005, Consumer: Economic Groupings in Asia Pacific, Asia Pacific Consumer Vol 42. 4/2005, Kuala Lumpur.

3 Consumers International Asia Pacific 2005.
} 
quently resulted in Konfrontasi (Confrontation) between Malaysia and Indonesia which lead to an end in the formation. What it is today the formation of ASEAN is the result of its third attempt at regional cooperation and stability that focus towards diplomacy via ASEAN Declaration which was engrossed on $8^{\text {th }}$ August 1967 with founding countries like Malaysia, Indonesia, Philippines, Singapore and Thailand as signatories to the regional pact.

Nine years later, the Treaty of Amity which was engrossed at the First ASEAN Summit on $24^{\text {th }}$ February 1976 marked the new beginning of a clear road map of ASEAN with reverence and focus towards a policy of non-interference and amicable settlement over territorial disputes through mutual respect of each nation independence, sovereignty, equality, territorial integrity and national identity. With its success this time round it has managed to attract other regional states like Brunei into its formation in 1984, Vietnam in 1995, Myanmar and Laos in 1997 and Cambodia in 1999.

ASEAN which focuses towards four basic areas of political and security cooperation, economic cooperation, functional cooperation and development cooperation, today takes pride its formation with bilateral and multilateral agreement with the international community ranging from ASEAN Free Trade Area and ASEAN Free Trade Agreement. ASEAN today, has cooperated in many sectors such as banking, finance, investment, health, environment, labour, law, energy, science, technology, telecommunication, information technology, tourism, transport, youth, culture and arts, transnational crimes, social welfare development, rural development, poverty eradication, disaster management and many more.

In tandem with an established and secured platform of regional cooperation over the years, ASEAN Vision 2020 found its footing at the $2^{\text {nd }}$ ASEAN Summit in December 1997. This was subsequently followed by Hanoi Plan of Action which was drawn up between (1999 - 2004): Declaration of ASEAN Concord II in 2003; Vientiane Action Plan (2004 - 2010) and Kuala Lumpur Declaration on ASEAN Charter in 2005 which was focused with a vision towards building an ASEAN Community by 2020 with relevance and purpose through the drawing up of constitutional documents conferring legal personality ${ }^{4}$ and institutional framework.

ASEAN position as a contributor to both regional and international forum, has received much recognition and acknowledgement from the Secretary General of United Nations which reiterated that:

"Today ASEAN is not only a wellfunctioning, indispensible reality in the region. It is a real force to be reckoned with far beyond the region",

Though territorial issues still takes centre stage, ${ }^{6}$ nevertheless ASEAN member states find solace in economic integration which is the basis of its foundation in the face of globalization and economic powerhouse. This is true since ASEAN took its first move towards economic integration a year after the signing of the Treaty of Amity

4 ASEAN Charter comprises of 13 Chapters, 55 Articles and 4 Annexes.

5 UN Secretary Kofi Annan at the Indonesian Council on World Affairs, Jakarta, $16^{\text {th }}$ February 2000.

6 China, Malaysia, Vietnam, Taiwan, Brunei and Philippines claim over South China Sea. 
with the signing of ASEAN Preferential Trading Agreement (PTA) in 1977 followed by creating ASEAN Free Trade Area (AFTA) in 1992 through the mechanics of Common Effective Preferential Tariff Scheme (CEPT). CEPT which were engrossed by ASEAN-6 was an initial move by earlier founding member taking the first step at reducing tariff to a range between 0 $5 \%$ by 2002 to a total elimination by 2010 . Grace period was extended to new members like Vietnam, Laos, Myanmar and Cambodia to adopt and realize CEPT by 2006 , 2008 and 2010 respectively with a total elimination projected latest by 2015 .

In 1996 quantitative trade restrictions and non-barrier tariffs were removed followed by ASEAN Customs Integration which was endorsed a year later with a view at facilitating trade and assist CEPT reaching its objectives through harmonization of procedures, valuation and tariffs including matters incidental thereto including harmonization of standards and conformance and green lane system to facilitate customs clearance. The approach towards trade facilitation and the removal of trade barrier has led ASEAN to form its ASEAN Consultative Committee on Standards and Conformance that is empowered with the task to align national standards with international and the drawing up of Mutual Recognition Arrangements (MRA) that focus towards conformity assessment in line with World Trade Organisation - Technical Barrier to Trade manifesto. With this approach ASEAN is committed to an end-goal of "One Standard, One Test, Accepted Everywhere"

Two years later in 1998, Framework on ASEAN Investment Area was drawn-up with a view of a single market and production base through a free-flow of direct investment. Subsequently in November 2000, ASEAN implemented its e-ASEAN Framework Agreement on electronic commerce that can be considered as the first agreement that stretches ASEAN commitment in realizing its vision with the absorption of international practices through assimilating, tailoring and fine-tuning of its domestic national laws to run in tandem with its framework on electronic commerce. This includes drawing-up of mutual recognition agreement on digital signature; secure transaction; intellectual property rights; data protection; consumer protection and privacy and alternative dispute resolution mechanism for online transaction.

In 2004, ASEAN committed itself a step further towards as a single entity when it addresses the community wide concern over health care system that is affordable through harmonization of standards and regulations of health services and consumer health particularly matters ancillary to ASEAN Security such as ASEAN Food Safety Policy. This includes sharing of information and database on disease control and the establishment of ASEAN Food Safety Network. This was then followed by the development and implementation of information technology that is the core foundation in information sharing through the National Computer Emergency Response Team (CERT) by 2005.In fact the dawn of ASEAN Community ${ }^{7}$ was the result of research undertaken by McKinsey and Com-

\footnotetext{
$13^{\text {th }}$ ASEAN Summit (Singapore) $20^{\text {th }}$ November 2007.
} 
pany ${ }^{8}$ which caution regional leaders of the need of unification in order to foster strength and remain competitive in the face of globalization. McKinsey was of the view that "The region is falling behind its rivals. Turning it into a single market would....help restore its economic lustre".

On $20^{\text {th }}$ November 2007, marking its forty-years of its amalgamation, ASEAN has decided to move further with a vision of progressing the formation into a dynamic, prosperous stable and competitive region with free flow of trade, investment and capital.

In its vision of building a single market similar to the European Union, ASEAN has gradually changed its characteristic focusing towards business opportunities and trade liberalization while putting its territorial issues at bay. ${ }^{9}$ With its population consensus of over $566^{10}$ million which is far more than the European Union, ASEAN is confident that it has a self-sufficient market with a gross domestic product exceeding USD\$ 1.173 trillion.

The ASEAN Charter which was engrossed by member states in November of 2007 marked a new beginning for ASEAN with a unique formation that has no central executive which mirrors the European Community. Nevertheless, with focus towards developing it into (a) a single market and production base (b) highly competitive

8 http://www.mckinsey.com/global-themes/asiapacific/asean-insights-regional-trends. (retrieved: Dec 21, 2017).

9 Territorial Disputes between Malaysia and Singapore over Batu Puteh and Middle Rocks, ICJ Judgment of $23^{\text {rd }}$ May 2008.

10 Edmund W Sim,Introduction to ASEAN Economic Community, Hutton \& Williams LLP, $11^{\text {th }}$ April 2008. economic region (c) a region of equitable economic development and (d) a region fully integrated into the global economy, ${ }^{11}$ ASEAN's envision that it could reach its target of 2020 much earlier by 2015, through implementation of various policies, collaboration and institutionalization approach thus making the ASEAN Economic Community a robust global supply chain.

ASEAN Blueprint that was strategically tabled provides a framework and roadmap which identify and address escrucial key issues which among others include the followings:

(a) to institutionalize a new mechanism and measures to strengthen the implementation of its existing initiatives including ASEAN Free Trade Area (AFTA). ASEAN Framework Agreement on Services (AFAS) and ASEAN Investment Area (AIA);

(b) to accelerate regional integration in the following priority sectors by 2010: air travel, agro-based products, automotive, e-commerce, electronics, fisheries, healthcare, rubber-based products, textile and apparels, tourism and woodbased products;

(c) to facilitate movement of business persons, skilled labour and talents; and

(d) to strengthen the institutional mechanism of ASEAN including the improvement of existing Dispute Settlement Mechanism ${ }^{12}$ to ensure expedi-

11 The ASEAN Charter 2007.

12 Territorial disputes between Cambodia and Thailand over Angkor Wat which will be addressed by consultation and consensus principles. In the event of no consensus the matter will be referred to theASEAN Summit for final deliberations. 
tious and legally binding resolution of any economic disputes.

Although ASEAN vision of a single community has been down-played and received much scepticism from many sectors, nevertheless the ASEAN Charter ${ }^{13}$ which was engrossed by member states is a legally ${ }^{14}$ binding document as compared to the initial Treaty of Amity ${ }^{15}$ which was a mere convention with no force of law. The key principles underlying the ASEAN Charter today is based on two pillars:

(a) shared commitment and collective responsibility in enhancing regional peace, security and prosperity; and

(b) enhanced consultation on matters seriously effecting the common interest of ASEAN

In consideration of this new ASEAN Charter, member states are expected to use and invoke on the basic principle of consultations and consensus ${ }^{16}$ which is the very foundation of its dispute settlement mechanism, rather than seeking referrals for such resolutions in international for a such as the World Trade Organization and the International Court of Justice. This approach is expected to prevent ASEAN from cleaning its dirty linen in public ${ }^{17}$ while at the same time give autonomy for the ASEAN Economic Council to decides regional issues. Alterna-

13 The ASEAN Charter comprises of 13 Chapters, 35 Articles and 4 Annexes came into force on $15^{\text {th }}$ December 2008.

14 The ASEAN Charter is registered with the United Nations: see Chapter 2 of the Charter giving ASEAN a legal personality.

15 The Treaty of Amity and Cooperation in Southeast Asia 1976.

16 The ASEAN Charter - Article 20 Chapter VII Decision Making.

17 International Court of Justice Decision on Pedra Bracnca/Pulau Batu Puteh, Middle Rocks and South Ledge, entered on $23^{\text {rd }}$ May 2008. tively, refraining themselves from seeking foreign mediation will boost and reflect itself as a region with greater stability and security while at the same time lucrative for foreign investors.

With this new approach that is well embedded it is expected that ASEAN will have a firm footing on dispute resolutions with the first to hear territorial issues between Cambodia and Thailand to be tabled before the Economic Community Council in 2011 under the chairmanship of Indonesia. Thus, the entrenched doctrine of noninterference and sovereignty of member states will ultimately be challenged against ASEAN Vision 2020. This is synonymous to the dictum Rodolfo C. Severino, Jr:

"Increasingly, ASEAN will have to summon regional cooperative solutions for problems that are more and more regional in scope. Indeed the way in which ASEAN is dealing and has to deal, with its most outstanding problems today sheds light on the way in which ASEAN will and must handle its problems in the new millennium: that is in a coordinated and cooperative way". ${ }^{18}$

On the other hand, ASEAN relations with international trading partners have developed gradually over the years. With its new formation under the new ASEAN Economic Community, ASEAN is expected to draw more investors to the region since the formation provides a sound and stable platform that is lucrative to foreign investors. Accordingly, in 2010 ASEAN has attracted some USD75.8 billion ${ }^{19}$ worth of foreign

18 Rodolfo C Severino. Jr. ASEAN Vision 2020: Challenges and Prospects in the New Millennium, Eight Southeast Asia Forum, Kuala Lumpur, $15^{\text {th }}$ March 1998.

19 ASEAN Secretariat. ASEAN Economy Resilient Grew by $7.5 \%$, Manado, Indonesia $14^{\text {th }}$ August 
direct investment and has a good track record over the past ten years with a steady growth in foreign direct investment at an annual rate of 19 percent. With trade ties forged on both bilateral and multilateral basis with powerhouse such as Australia, China, Canada, European Union, India, Japan, Korea, New Zealand, United States of America, Russia and Pakistan, ASEAN is expected to accelerate its economic partnership, trade and investment liberalization.

ASEAN realised that the cornerstone of flourishing trade lies with its free-trade agreement and such memorandum of understanding with international community. Such crucial ties would not be fruitful if it fails synchronising its backend of removing trade barrier through trade conformance and adaptation of international practices and procedures Since ASEAN is well aware that its primary objective is to remove trade barrier which is often associated with differing standards, testing and certification, it has set-up the ASEAN Consultative Committee on Standards and Quality (ACCSQ) which is a collaboration of member states mandated to look into and ensure the marketability of its product and services not only regionally but globally. Harmonising standards which is in par with international standards will ensure its objective of "One Standard, One Test, Accepted Everywhere".

Trade partnership does not only signify that ASEAN is being accepted and recognized by the international players but alternatively it is an indication that its market and target audience is larger and wider with a huge consumer market. As per dictum of Philippines President Arroyo that ASEAN-

2011 (www.asean.org), 43 ${ }^{\text {rd }}$ ASEAN Economic Meeting (AEM) 10-11 August 2011.
China free trade area "would give birth to a market of 1.8 billion consumers or almost one-third of humanity" ${ }^{20}$ ASEAN trade exports has steadily increased over the years venturing into major markets such as the United States, European Union and Japan and it is hoping to reach its target of USD\$ 1.173 trillion in gross domestic product with a zero-tariff market through streamlining of procedures by providing pre-clearance and pre-entry classification services and implementing WTO Valuation Agreement.

On a similar note, the ASEAN Single Window which was set-up to simplify and streamlined procedures according to WTO and UNTDED framework is an addition to trade facilitation which is focus towards integration, enhancing trade efficiency and competitiveness while concurrently reduces time and cost associated with customs clearance. Although some member states like ASEAN-6 has embarked on the program much earlier, nevertheless it is expected to be fully operational and adopted by all remaining ASEAN-4 member states by 2012 .

At the $43^{\text {rd }}$ ASEAN Economic Meeting (AEM) which was held in August 2011, ASEAN reflected a matured growth in domestic demand with an expansion of 7.5 percent in 2010. To date ASEAN has already reflected a 5.7 percent of domestic growth in 2011 with a projection of 6.4 percent by year ending 2011. Similarly, ASEAN merchandise trade grew 32.9 percent in 2010 with trade valued at USD\$ 2.04 trillion $^{21}$ from the previous year of

20 Rodolfo. C. Severino. Jr, ASEAN: Advancing $A P E C$ 's Core Purposes, $12^{\text {th }}$ APEC Ministerial Meeting, Bandar Seri Begawan, Brunei, $13^{\text {th }}$ November 2000.

21 ASEAN Secretariat, ASEAN Economy Resilient Grew by $7.5 \%$, Manado, Indonesia $14^{\text {th }}$ August 
USD $\$ 1.54$ trillion, far exceeding the earlier USD $\$ 1.173$ trillion mark. To date ASEAN has kept a steady pace in reaching its AEC Vision by 2015, achieving a scorecard of 68 percent of dealings which has been completed under its Phase I (2008-2009) and Phase II.

At the $13^{\text {th }}$ ASEAN Mekong Basin Development and Cooperation Ministerial Meeting which was held on $29^{\text {th }}$ July 2011 , statically, ASEAN has already embarked on some 37 project of the total 51 with some 14 projects at bay that requires funding of about USD\$ 272.5 million $^{22}$ in total. These projects covers a wide array of sectors ranging from infrastructure, trade, investments, agriculture, forestry, mineral, industry, tourism, human resources development and science and technology. In consideration of its determination, consistency and continuous effort of realizing projects into practice ASEAN has been able to progress and come to terms with the international community. The ability to remain proactive including adopting and assimilating international protocols makes it an entity open to global challenges and demand.

Endless effort to synchronise and harmonise its mechanics has prima facie proven its commitment with an increase in trade expansion over the years. The ability to honour and execute agreements that has little legal implications in the initial stages has made it a unique formation with credibility. In fact the manner in which ASEAN works today (with no central authority like

2011 (www.asean.org), 43 ${ }^{\text {rd }}$ ASEAN Economic Meeting (AEM) 10-11 August 2011.

22 ASEAN Secretariat. 13 ${ }^{\text {th }}$ ASEAN Mekong Basin Development and Cooperation Ministerial Meeting which was held on $29^{\text {th }}$ July 2011 (www.asean.org). the European Union) is commendable since the results of its cooperation reflects its commitment in toto. Although many are of the view that ASEAN should adopt multilateral negotiations with the international community instead of bilateral negotiations undertaken at national level, nevertheless such commitment acts as a catalyst and open doors for multi-lateral negotiations in later stages which benefits the region as a whole.

In summary, the writers are of the opinion that the ASEAN Charter has and will act as a spring board for greater stability and cooperation within the region. Although territorial disputes may be inevitable and appear to some factions as the down-side of the region, nevertheless the issue of territorial disputes is part and parcel of nation sovereignty in any corner of the world from the dawn of time. It is the manner in which the issues are settled are far more important since it makes way for tolerance and greater unity in the future. The efforts and length that member states have committed to ensure that the region is stable can be reflected by its achievement in the economic sector. The focus towards integration, synchronization and institutionalization has managed to put regional territorial issues at bay. The researchers are of the opinion that economic sustainability in the midst of global challenges has made ASEAN a closely knitted formation that it was before. It is of the researcher opinion that the economic sector will pave way for greater cooperation in many other sectors including the future development of its legal structure ${ }^{23}$ that is conducive to its trade, economic and business.

\footnotetext{
23 The e-ASEAN Framework on Electronic Commerce.
} 
Progressively, ASEAN will through its governance of permanent representative and its inter parliamentary assembly work closely towards building a more synchronized system that is accepted by member states. For a start, the researcher could foresee the establishment of a legal structure that will be similar to the European Union that will be empowered to pass directive, resolutions and orders for the benefit of its economic sectors since this is the only sector that will benefit all member states with nothing stake. Similarly, the ever increasing population consensus of ASEAN provides the region with its own market larger than the European Union and as such the forseeability and commitment of member states to surrender to the will of region as a whole is promising in advancing its economic agenda.

Finally the will and continuous commitment of ASEAN to do away with its preestablishment conflicts and the ability to entice new member states into its formation from its initial five has proven to international community that the establishment is a force to be reckoned with in the near future although they may seem rather slow as compared to the European Union in terms of progress even though they were established with a mere $10^{24}$ years gap between one another.

\section{Consumer Protection Legislations}

As previously discussed in above, though ASEAN is built on similar background as the European Union with multifarious sets

\footnotetext{
24 The Treaty of Rome 1957 and The ASEAN Declaration 1967.
}

of laws ${ }^{25}$ emanating from different states, nevertheless the European Union is built on a different framework that obliges its members to legally conform to Directives, Resolutions or Orders from the European Commission.

Although the formation of ASEAN has been in existence for more than forty-four years, nevertheless the formation is based on a voluntary union with no legal framework to start with. Though the ASEAN Charter which was enacted in 2007 has given it a legal personality with formation similar to the European Union with parliamentary representative, unfortunately its legal framework is still at its infancy stages due to its non-interference policy which is currently being adopted by member states.

Contrary to the common perception, it is hoped that ASEAN will focus and gives priority towards harmonising its consumer protection laws and regime since this the basic foundation and critical cornerstone that will support itself in its vision of achieving its economic progress and success. As stated by Dr Sothi Rachagan:

"For it is consumers, who will
determine the success and
sustainability of the ASEAN Eco-
nomic Community" 26

Though ASEAN is ambitious in its economic initiatives through ASEAN Free Trade Agreement (AFTA), Free Trade Agreement (FTA) and Multilateral Agreement with powerhouse like China, European Union and United States, nevertheless

\footnotetext{
25 Noboyuki Yasuda in Law and Development in East and South East Asia edited by Christoph Antons, Routledge Curzon, London, 2003.

26 Dr Sothi Rachagan, Southeast Asian Conference on Consumer Protection $28^{\text {th }}-29^{\text {th }}$ November 2005, Kuala Lumpur.
} 
ASEAN should focus towards synchronising its back-end to ensure its 600 million consumers are afforded with the state-ofthe-art consumer protection laws and product safety mechanism since safety can synonymously be equated with security.

ASEAN lack of commitment in the areas of consumer laws to date maybe attributed to the foreseeable counter-productive (legal) integration processes that may be seen as an attempt to obstruct or hamper trade facilitation and investments. The approach of putting trade on the highest pedestal while considering consumer protection as an obstacle is in fact a common norm that has been accepted in salient form around the world with the exception of European Union and Mercosur (South American Common Market).

Contrary to the view that economic integration outweighs consumer protection, nevertheless if we were to analyse the surrounding situation we would have to come to terms that greater consumer protection will only increase trade and demand for goods which in turn will generate greater demand and trade expansion. ASEAN at this juncture should always review its commitment towards greater integration in tandem with consumer protection since it is a fundamental aspect that affects anyone and everyone within the region or the globe alike. Within the region itself needless can be said because some new member states like Laos and Cambodia have just only begun enacting its consumer protection laws to protect its consumers since free-trade connotes nobarrier trade that more often than not it exposes consumers to vulnerability especially more so for new member states who maybe lacking in consumer protection laws and proper mechanism in place. The writers are of the opinion that it is only through harmonizing process that consumer protection law will ASEAN be able to help member states which lack the consumer protection structure. This concurrently will save a huge amount of time while in the same premises introduce a new regime which reflects the current ASEAN consumer protection law and policy collectively.

The comparative studies drawn on the formation and legal framework of the European Union and legislations such as the General Product Safety Directive (EU) and Consumer Protection Unfair Trade Regulations 2008 (UK) and, it can be submitted at this juncture that product safety laws in the European Union and the United Kingdom are far more comprehensive and wide in its application in ensuring that consumer within the region are afforded with a consistent standards and safety laws that is to a many extent reliable, dependable and assuring. Though, this can partly be attributed to its commitment via the European Commission over the years and the enthusiasm of member states to adopt directives in the best interest of its consumers and single market requirements.

The current fashion of upholding the principle that safety does not end with a reasonably safe product but a for useably safe product $^{27}$ has swelled the ambit and width of accountability among manufacturer in ensuring that they comply with a higher threshold of product safety. Similarly, by injecting the principle of due care and diligence, ${ }^{28}$ the European Union has also today managed to bolster the consumer protection

\footnotetext{
27 Balding v Lew Ways Ltd (1995) 159 J.P. 541.

28 Section 33A CPUTR 2008.
} 
further by encouraging businesses and manufacturer to inculcate best practices of voluntary removal of unsafe goods in the market. This approach does not only infuse businesses to be proactive but concurrently it obliges them to be accountable for the products they market within the union.

In the same premises and from general observation it has also been revealed that the tendency of the judiciary ${ }^{29}$ to apply the theory of Precautionary Principle ${ }^{30}$ has signal the current stand of the courts in applying consumer protection in totosince the underlying principle in relation to safety standards does not accommodate or have rooms for inconclusiveness, imprecision or insufficiency in the absence scientific study. ${ }^{31}$ The enactment of the General Product Safety Regulations (GPSR) ${ }^{32}$ in the United Kingdom via the General Product Safety Direc-

29 Court of Justice C-434/02 - Arnold Andre GmBH \& Co v Landlart des Kreises Herford (2004) European Court Report at page 1-11895.

30 Precautionary Principle refers to " threat of substantial serious or irreversible harm to consumers but there is clear scientific uncertainty over the extent of threats posed"

31 Court of Justice C-210/03 - Swedish Match AB and Swedish Match UK Ltd $v$ Secretary of Health (2004) European Court Report at page 1-11893 Art 8 prohibits placing or the market of tobacco for oral use. The court considers "snuff" falling within the ambit of chew tobacco intended for oral use. The court applied the rules of precautionary principle since the use of tobacco and snuff is associated with cancer of the mouth even though the Royal College of Physicians of London states that smokeless tobacco is 10-1000 times less harzadous than smoking and is being used as a substitute for those intended to quit smoking despite the fact that Sweden charts a low rate of tobacco related illness from the use of snuff. Based on the fact that it is attracting young people and he existence of a minimum risk associated with cancer of the mouth the court applied precautionary principle.

32 GPSR 2005 came into force in $1^{\text {st }}$ October 2005: European Commission Directive 2001/95/EC dated $3^{\text {rd }}$ December 2001. tive (GPSD) of the European Commission further in still consumer confidence since the regulations primary purpose is to fill the gaps or lacunae ${ }^{33}$ to safety that may have slip through piecemeal legislations enacted over the years. The GPSR ensures that products that are made available in the market are in compliance with the GPSD with regards to essential requirement of health and safety being a paramount concern of consumer protection. ${ }^{34}$ This approach was adopted since the European Union was aware that it was impossible to react to every product that exist or may be developed since the essence of safety standards that is heavily reliant on technical directive may go against the fundamental values in the establishment of a single market ${ }^{35}$.

At present, though ASEAN member states have to a certain extent legislate consumer protection legislations in the past that is meant to protect its consumers through domestic laws nevertheless they differs greatly $^{36}$ since the mechanics that tune that fine-tune (harmonise) laws in the European Union through the European Commission is unavailable or at this point of time have yet to be tested by parliamentary representative to the ASEAN Economic Council. Although there are disparities in terms of scope and width of each national legislation, nonetheless the primary objective of these legislations are well defined to protect consumers

33 GPSR 2005 provides a catch all provisions to safety.

34 Article 129a of the Treaty of Rome cross reference with GPSD 2001/95/EC.

35 Article 100a of the Treaty of Rome.

36 Philippines Consumer Protection Laws requires every product be tested while other member states consumer protection laws are subject to by-laws or regulations passed under the Act for a particular category of product or products deemed necessary by the Minister. 
with criminal sanctions even though they may seem less comprehensive as compared to their counterpart in the European Union.

Nevertheless, despite its weakness in this respect, some ASEAN member states like Malaysia and Singapore are quick to adopt interim measures to protect its consumers when and where necessary. Such example is the recent enactment of sectoral approach to consumer protection in the instance of Malaysia through the Consumer Protection (Safety Standards for Toys) Regulations 2010 and Consumer Protection (Certificate of Approval and Conformity Mark of Safety Standards) Regulations 2010 (as amended) which for the first time since its enactment in $1999^{37}$ regulate conformity and safety standards for toys.

Although the above enactment is well accepted by consumers domestically in their respective countries nevertheless it reflects a negative signal of distrust in the ASEAN system which is slow to react not only in this instance but in many other areas of conformance that is still outstanding and hanging.

Similarly in the same tenor the need to protect its consumers (particularly children from defective toys that are rampant worldwide) Singapore also enacted a new piece of legislations, the Consumer Protection (Consumer Goods Safety Requirements) Regulations 2011 (CGSR 2011) which come into force on $1^{\text {st }}$ April 2011. This new piece of legislation though was initially intended to protect consumers particularly children from defective toys ${ }^{38}$ is in fact as wide in scope

37 The Consumer Protection Act 1999 (Malaysia).

38 Research undertaken by Consumer Association of Singapore (CASE), Consumer Protection (Consumer Goods Safety Requirements) Regulations 2011, Information Booklet Edn 1.1. that is comparable to the General Product Safety Directive of the European Union in its enactment. In this respect, the CGSR 2011 covers a wide array of consumer products since the new legislation covers unregulated consumer goods which are expected to affect some $15,000^{39}$ consumer products. Though the scope of the new legislation is well received by consumers since the new legislations requires goods sold in Singapore needs to conform to international, regional and national safety standards of the International Organization for Standardization (ISO); International Electrotechnical Commission (IEC); European Committee for Standardization (CEN) and United States Standard Setting Organization (ASTM) nevertheless there seem lacking in a mandatory common conformity mark like those categories of goods that are regulated.

Even though we could agree that most member states have some form of consumer safety legislations ${ }^{40}$ in place or could the least rely on general liability under the law of tort for redress, we could summed-up at this juncture that there is a prerequisite for a collaborative effort among ASEAN member states in ensuring consumers are well protected through a comprehensive product safety laws that are similar across the board in its essence even though they may differ in form.

39 Consumer Protection (Consumer Goods Safety Requirements) Regulations 2011 Information Booklet Edn 1.1 at page 11.

40 Consumer Protection Act 1999 (Malaysia); Consumer Protection Act 1979 (Thailand); Law on Consumer Protection 1999 (Indonesia); Consumer Protection (Trade Description and Safety Requirements) Act 1975, Consumer Protection (Fair Trading) Act 2003,Consumer Protection (Consumer Safety Requirements) Regulations 2011 (Singapore) andThe Consumer Protection Act 1990 (No.7394) (Philippines). 
ASEAN should always utilise and prioritise its legal mechanism under the new ASEAN Charter since it is the very foundation that will spur member states to comply to better and a more comprehensive consumer protection laws which subsequently will facilitate a healthy and more synchronized trade practices that is not only being well accepted regionally but on an international scale.

ASEAN should do away with the impression that stringent consumer protection regulations will always be a hindrance to trade and shun international players from reaching its market but should in turn always look at it as a tool that will assist it in increasing trade exports since its product is in compliance with safety laws and standards. Such is the benefit derived from stringent practices employed in the European Union where its exports are well received to an extent unconditionally by global market. The need for stringent approach to protect consumers is now more desirable than ever since time and time again consumers are exposed to defective goods that falls below the required standards. Such could be attributed to the lack of consumer protection laws that has enabled global players to use the region as a dumping ground for sub-standards goods. In fact ASEAN should be the least worried about international perception towards its proposed consumer protection regime since even without international players ASEAN itself have a sufficient market of its own larger than that of the European Union. Member states like Singapore and Malaysia has realized this trend and has counter measures in place with new legislations that is meant to deter such goods from generally or sectorally slipping into its market. With a new proposed directive on consumer safety law ASEAN will be able to protect its consumers while instilling consumer confidence and assurance in its safety processes.

In fact, laws generally should be well received as it is a vehicle and an instrument that will oblige those affected to coerce to the standards stipulated by the governing authorities. It is a form of order that must be adhered to acting as deterrence against arrant and irresponsible traders. Though previously trade barriers were erected with the sole purpose to protect consumers but these policy took a turn around in an opposite direction with a advent of single market which supposedly should reflect an increased in better governance since goods now moves freely within the region than it was before. Event hough the concept of a single market is well accepted by ASEAN nevertheless ASEAN should always consider the shortcoming to every advantage in a sense that consumers are now more exposed and vulnerable than it was before.

The working structure of the European Union should be usurp by ASEAN in its entirety since the formation has shown much success in its union The relations and workings between the need for a single market and consumer protection is equally addressed as stated:

"Consumer policy is a part of the union's strategic objective of improving the quality of life of all citizens, In addition to direct action to protect their rights, the Union ensures that consumer interest are built into EU legislations in all relevant policy areas. As a single market and the single currency open trading borders, as use of the internet and electronic commerce grows and as the service sector expands, it is 
important that all 430 million citizens in the 25- nation Union benefits from the same high level of consumer protection",41

In submission, the writers are of the opinion that a consumer protection directive in relations to safety standards is indispensible since it is the vehicle that will drive the single market and economic interest of consumers both regionally and globally.

Even though ASEAN maybe reluctant due its non-interference policy we have to understand that the non-interference policy that was referred to initially plays no part in their economic sector but has reference to political and territorial structure only. It is in this respect that the researcher is of the opinion that a GPSD may receive endorsement from member states since it concurrently projects a better structure while at the same time promote trade exports. It is hoped that the proposed GPSD with similar focus as the EU will give directions that will be adopted by member states in essence rather than form since the new ASEAN Charter was enacted to facilitate the concept of a single community.

Although the writers are of the opinion that ASEAN has to date no legal structure to support its legal mechanics and laws through courts structure, nevertheless if consumer safety laws are harmonised in a stringent manner as it should there would be no need or avenues to resort or implement court structure at regional level to support its laws since member states will be able to address legal issues domestically from the same standpoint since the laws (GPSD) are similar in essence and form. This is in fact a

\footnotetext{
41 www.europa.eu.int/pol/cons/overview_en.htm. (retrieved: Dec 21, 2017).
}

more practical approach since it will not encroach into concept of sovereignty of any one nation. In fact the more stringent the process (safety standards laws),the less will be required for a redress mechanism.

The writers are of the opinion that through harmonising of its proposed safety standards laws, ASEAN will be able to close the gap swiftly and pull member states that are left behind in consumer protection policy to be in par instantaneously. The application of a blanket directive is in fact a swift mode to a quick and proper functioning of its mechanics especially so where member states are coming from different background and structure. It is in fact the means and a practical approach to do away with differences that exist and work on similarities which are in tandem with the synchronizing effect of a single community.

Last but not least, the researchers are of the opinion that the proposed Draft of General Product Safety Directive for ASEAN will have to take into account and addressed the following issues. In its scope it should include the following substance such as:

(a) principle of general health and safety requirements;

(b) mandatory standards for all goods (all goods have to be tested - regulated goods will be in compliance with technical regulations while unregulated goods will have to be in compliance with a minimum ISO/IEC standards);

(c) dilute technical regulations and focus towards general liability to safety ${ }^{42}$

42 GPSR 2005 (UK) - Guidelines for Businesses, Consumers and Enforcement Authorities. Guidance Notes Aug 2005, Para 1.2 - The purpose of the General Product Safety Directive is to ensure that all products intended for or likely to 
(since this is the current trend in the EU in overcoming the shortfall in time and keeping in pace with thousands of new products being developed yearly);

(d) all products that circulate within the ASEAN region must be marked with CA (Conformity ASEAN) Mark and to do away with national marking that maybe confusing to consumers;

(e) to apply the regulations in essence rather than form(focus on standards rather than law enforcement);

(f) to inculcate professional diligence ${ }^{43}$ since it provides for self-regulations (since this is a two way method to reduce the workload of enforcement agencies);

(g) to develop a central database to ensure possibility of tracing and product recall. This includes a consumer friendly database that is easily accessible to consumers to ensure everyone can play a part in policing sub-standard goods; and

(h) enacting the principle that safety does not end with a reasonably safe product but a for useably safe product ${ }^{44}$ will extend the ambit and width of accountability among manufacturer in ensuring that they comply with a higher threshold of product safety in line with UK GPSR $2005^{45}$ and UN Guideline on

be used by consumers under normal or reasonably foreseeable conditions are safe.

43 Section 3(3)(a) CPUTR 2008 (UK) "professional diligence" means standard of special skill and care which a trader may reasonably be expected to exercise towards consumers which commensurate with either (a) honest market practice in the traders field of activity, or $(b)$ the general principle of good faith in the traders field of activity.

44 Balding v Lew-Ways Ltd (1995) 159 J.P. 541.

45 GPSR 2005 (UK) Para 1.2 The purpose of the General Product Safety Directive.....intended for
Consumer Protection $1985^{46}$ which indirectly extends both pre and post market self-regulations. ${ }^{47}$

The presumption of encroaching into domestic laws should not be regarded as an obstacle since ASEAN non-interference policy has no connotation to its economic sustainability sectors but should only be upheld on issues of territorial disputes and politics. This is in fact the underlying factor why the e-ASEAN Framework is a success in its implementation swiftly with member states implementing its digital signature framework which is more complex than the issue in hand because unlike e-commerce which is new, safety standards has been in existence within ASEAN member states for a long period of time.

\section{Standards and Testing Agencies in ASEAN}

Product standards are the most critical limb or core value which goes to the root in ensuring consumers are afforded with a safe product in the market since these products are either used or consumed by almost 600 million $^{48}$ consumers regionally on a daily basis. Although we have to agree that not all countries within the region developed at the

or likely to be used by consumers under normal or reasonably foreseeable conditions are safe.

46 Clause 11 under Physical Safety - Government should adopt or encourage....ensure that products are safe for either intended or normally foreseeableuse.www.ask2knetwork.org/guidelines /physical-safety. (retrieved: Dec 21, 2017).

47 GPSR 2005(UK) Para 6.1 “...to undertake relevant activities (where appropriate) to help ensure that a product remains safe throughout its reasonably foreseeable period of use"and Para

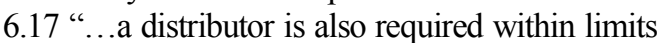
of his activity to participate in monitoring the safety of products that he supply and pass on information on the product risks."

48 www.asean.org - population consensus. 
same pace equally and has the necessary technical resources or state of the art scientific knowledge, nevertheless most of the ASEAN permanent member states (Singapore, Malaysia, Thailand Indonesia and Philippines) as discussed in these research have the required infrastructure that is to a certain extent reliable in its form. Some ASEAN member states have put inclination into the importance of standards as early as $1954^{49}$ in the case of Indonesia while the rest appreciate its importance in the 1960s.

With the removal of trade barrier and free flow of goods, ASEAN will need to adopt a proper mechanics that will ensure that the benefits of trade expansion will not overshadow the detrimental effect of the state consumer vulnerability of being exposed to defective and sub-standards products in the midst of trade facilitation and economic sustainability faced by challenges posed by international powerhouse. Although some member states of ASEAN are considered well-equipped to face the challenges, nevertheless the remaining member states are still developing and can be in an unfortunate position of being used as a dumping ground for defective goods since these countries may lack the technical expertise to appreciate the danger of products that flows into their market and to consumers alike. The lucrative prices minus the safety have to a great extent undeniably enticed importers to seek such product in the prospect of receiving higher profit margin.

This is the result of two-tier standards which differs in form - of which goods with a higher standards will be exported to coun-

49 Yayasan Dana Normalisasi Indonesia (YDNI); Member of International Electrotechnical Commission (IEC). tries with stringent standards and requirements while a lower standards are being exported to countries without proper general safety requirements. This has brought about the concept of dumping ground abuse for sub-standard goodsin which some countries applies mandatory standard for same goods while other applies voluntary standards. In the same instance product that is being recalled in one country may not be recalled in others due to discovery and lower threshold of liability which seems almost nonexistence. It is not fair, sufficient or reasonable to expect consumers to be able to appreciate the danger of goods when such standards can only be appreciated by technical standards and competent assessment bodies.

Although the ASEAN Consultative Committee for Standards and Quality (ACCSQ) was established way back in 1992 nevertheless the formation is considered slow in its progress since to date ASEAN has yet to establish technical directive/regulations with a legal punch. Although sectoral recognition for Electrical and Electronic Equipment with the concept of tested once tested everywhere was adopted through ASEAN Mutual Recognition Arrangements (MRA) nevertheless the EEE mark that was adopted to signify conformity standards based on harmonizing 59 international standards, 71 safety aspects and 10 EMC standards ${ }^{50}$ through ISO/IEC guidelines seems to vanish and is not being exclusively used in the market. This may be due to the voluntary nature of compliance that was associated with the MRA.

50 Standards and Conformance- Essential for Business Success and ASEAN Efforts. ASEAN STANDARDS AND QUALITY. ASEAN Secretariat. www.asean.org. 
Although ASEAN may be quick to identify certain sectors as being important nevertheless ASEAN seems rather quick to fall into the same trap as the European Union such as being bogged down with technical regulations that through experience has hamper its concept of proper functioning of a single market. ASEAN should realise that the European Union has adopted a concept of common policies ${ }^{51}$ through legal framework which is the backbone of its successful multinational integration that is lacking in the ASEAN framework. ASEAN should at this juncture look back and focus on lessons to be learned from the EU experience. ASEAN should at this point of time adopt the concept of essential safety requirements as opposed to technical standards which could be far-fetched in reality due to the concept of single market, trade facilitation, proper functioning of internal market and the pace at which new products are being developed and introduce yearly which goes against the very mechanism of removing Technical Barriers to Trade (TBT).In fact with the removal of trade barrier and scientific advancement there is no room for twotier (mandatory and voluntary) safety standard assessment. Though this may seem a move away from the initial EU practice but the need to have all product tested is advent when the GPSD was later enacted that applies silently to all goods.

The writers are of the opinion that ASEAN should at this point of time adopt the concept of mandatory standard for all goods that requires some goods classed as regulated goods be governed by technical

51 Common Policies of adhering to European Commission (Orders, Directives, Regulations, Decisions, Recommendations and Opinions \& Resolutions). directives and standards while unregulated goods have to comply with a minimum ISO/IEC standards instead of the current practice of adopting the ISO/IEC guidelines a foundation for mandatory standards since we could at this juncture appreciate that ISO/IEC standards are a mere reflection failure test contrary to safety test which is being beseech. This is in fact a true reflection of the reliance and reliability ${ }^{52}$ of safety standards being applied by the courts.

Standards and testing agencies in ASEAN which works collectively under the umbrella of ASEAN Consultative Committee on Standards and Quality (ACCSQ) should take a positive and proactive step in circumventing the issues which arises from liberalization of trade and free flow of goods. In fact ACCSQ should be more cautious in protecting the interest of consumers within the region. With China being the largest trading partner within the ASEAN region, ACCSQ should have provided better policing and adopt a more stringent approach particularly with China since its exports is often questionable on the grounds of safety compliance. Such is the statistics ${ }^{53}$ shown by the European Union Rapid Alert System that monitors and issues notices of defective and dangerous products floating in the market. Over the years China has a reputation of having the highest product recall even though stringent framework has been adopted in the European market. If such product can slip into the European market what more can be said about the ASEAN market where its standards and safety framework is still at its infancy stages.

52 Presumption of standards under the GPSR 2005: see Balding v Lew-Ways Ltd (1995) 159 J.P. 541.

53 See Appendix - EU RAPEX ANNUAL Report 2010. 
In fact, China-ASEAN trade is currently worth about USD $\$ 292.8$ billion in $2010^{54}$ with a significant increase of $35 \%$ from the previous year of 2009. What need to be closely addressed are exports from China which surge to a hefty $30.1 \%$. Though increase reflects an expansion that is welcome by ASEAN member states, nevertheless ASEAN should concurrently perceived that the greater the exports are, the higher the risk of vulnerability to defective goods being exposed to its consumers if ASEAN has no safety mechanism that will deter errant players.

Though some aspect of European Union safety mechanism has been initiated and adopted by member states like Thailand through maintaining a suitable network for ASEAN Rapid Alert System for Food \& Feed (ARASFF) ${ }^{55}$ nevertheless RAPEX for Non-Food \& Feed has yet to be adopted fully by member states though they have initiated the ASEAN notification system within their regional network. What ASEAN should be concerned is not about the reliability of their notification system but instead should focus on erecting a standardisation safety mechanism which has no room for defective goods which should run in tandem with Customs Clearance that is currently being tested under a pilot project by Singapore.

ASEAN standards and testing agencies in fact have the entire required infrastructure that is crucial in the implementation of standardization processes. In fact all member states that is discussed in this research is in

54 Linda Yulisman, "No talks with RI on ASEAN Free Trade Pact China, Jakarta Post, $13^{\text {th }}$ April 2011.

55 ARASFF Pilot Project (TH/SPF-128404). one way or another has affiliation with Accredited Laboratories on matters relating to calibration, testing, quality management system, environmental management system, including medical testing and good laboratory practice. In fact some member states are actively involved to the position of technical committee, technical council and technical management board at international level. In fact the vast experience and wealth gained over the years through its involvement in standardisation processes should in many ways be an asset in the development and proper functioning of safety standards under the umbrella of ACCSQ.

The standardisation process that is currently being employed at domestic level should be collaborated in order to assimilate the best practices in the interest of ASEAN. Although the recent enactment of new legislations among member states like Malaysia and Singapore to circumvent issues that arise from standardisation and product safety nevertheless only reflect the division in commitment since some ASEAN states have not adopted similar measures while the width and ambit of the legislations enacted between Singapore and Malaysia is wide in one sense and narrow in the other.

Although ASEAN Consultative Committee on Standards and Quality have managed to identify 8 sectors that requires attention and setting up of sub-committee, nevertheless these committee seems rather slow in its technical dossier. Although initially the EEE mark was initially adopted for electrical and electronic equipment sectors nevertheless ASEAN may have realised that sectoral marking seems impractical due to many sectors that were subsequently identified. From this angle one could conclusively 
derived to a conclusion that ASEAN has failed to look at issues on a bigger scope which subsequently led to a sudden death of the EEE mark. In fact in August 2007 the draft proposal for harmonization process addressed the issue of conformity mark but as it is ASEAN is slow in its execution that leads to the postponement of the common conformity mark many years later.

ASEAN should always work as a single entity in ensuring that its standards is accepted within the region and the international community since standard and compliance system is a vehicle that will drive the consumers within the region into a more secure territory. Should the standard mechanism be well employed non-compliance will be a thing of the past and the need for a complex legal framework (courts, tribunals and redress mechanism) can be diluted to the point of just legislating ASEAN Directives that is well observed by corporations is in its entirety and concurrently enforced and incorporated as a part of national domestic law.

\section{CONCLUSION}

The inevitable and foreseeable need for ASEAN to knit the gap of (product safety) diversity among member states and to focus on similarities are crucial in the proper functioning of the internal market and/or single market in 2015. The swift progression and commitment in the field of consumer protection and product safety in the European Union is in fact a blessing and distinct advantage for ASEAN since it provides the necessary framework and mechanism that has been previously tested. As mentioned, ASEAN should continue to review, analyse and adopt the strength and current practices in the EU while at the same time remedy weaknesses and shortfall that exist in order to improve, enhance and refine its consumer protection mechanism. The obvious need for across the board ASEAN Product Safety Directive that is consistent will ensure that none of its new member states are left behind in its progression towards building a secured consumer market that prioritises on health and safety concerns of its consumers. It is vital that the proposed ASEAN Directive reflect the trade aspirations of the community as a whole as well as to complement and supplement the local legislations of member states. The future and success of the ASEAN member states will without doubt hinges on the Directive which awaits implementation.

Note: The views expressed are those of the writers and in no way reflect the official opinion of the ASEAN Secretariat.

\section{REFERENCES}

ARASFF Pilot Project (TH/SPF-128404).

Asean Secretariat. 13 ${ }^{\text {th }}$ ASEAN Mekong Basin Development and Cooperation Ministerial Meeting which was held on $29^{\text {th }}$ July 2011 (www.asean.org).

Asean Secretariat. ASEAN Economy Resilient Grew by 7.5\%.Manado, Indonesia 14th August 2011 (www.asean.org); 43 ${ }^{\text {rd }}$ ASEAN Economic Meeting (AEM) 10-11 August 2011.

Balding v Lew Ways Ltd (1995) 159 J.P.541.

Consumers International Asia Pacific. 2005. "Consumer: Economic Groupings in AsiaPacific." Asia Pacific Consumer Vol 42. 4/2005. Kuala Lumpur.

Court of Justice C-434/02 - Arnold Andre $G m B H$ \& Co $v$ Landlart des Kreises Herford (2004). European Court Report. 
Consumer Association of Singapore (CASE). Consumer Protection (Consumer Goods Safety Requirements) Regulations 2011.

Consumers International Asia Pacific 2005.

Court of Justice C-210/03 - Swedish Match $A B$ and Swedish Match UK Ltd $v$ Secretary of Health(2004) European Court Report.

CPUTR 2008 (UK).

Edmund W Sim. 2008. Introduction to ASEAN Economic Community. Hutton \& Williams LLP $11^{\text {th }}$ April.

European Court Report 2004.

GPSR 2005 (UK) - Guidelines for Businesses, Consumers and Enforcement Authorities.

http://www.mckinsey.com/globalthemes/asia -pacific/asean-insights-regional-trends. (retrieved: Dec 21, 2017).

International Court of Justice Decision of $23^{\text {rd }}$ May 2008. Territorial Disputes between Malaysia and Singapore over Batu Puteh and Middle Rocks.

Linda Yulisman. "No Talks with RI on ASEAN Free Trade Pact China". Jakarta Post.April $13^{\text {th }} 2011$.

Noboyuki Yasuda. 2003. In Law and Development in East and South East Asia edited by Christoph Antons, Routledge Curzon, London.
RAPEX Annual Report 2010. Keeping European Consumer Safe. Luxembourg Office for Official Publications of the European Communities 2011.

Rodolfo C Severino. Jr. ASEAN Vision 2020: Challenges and Prospects in the New Millennium. Eight Southeast Asia Forum. Kuala Lumpur. 15 ${ }^{\text {th }}$ March 1998.

Rodolfo. C. Severino. Jr.ASEAN: Advancing APEC's Core Purposes. 12th APEC Ministerial Meeting. Bandar Seri Begawan. Brunei. 13 ${ }^{\text {th }}$ November 2000.

Sothi Rachagan. 2005. Southeast Asian Conference on Consumer Protection 28th $29^{\text {th }}$ November. Kuala Lumpur.

The Asean Charter.

The Asean Declaration 1967.

The e-ASEAN Framework on electronic commerce.

The Consumer Protection Act 1999 (Malaysia).

The Treaty of Amity and Cooperation in Southeast Asia 1976.

www.asean.org - population consensus. (retrieved: Dec 21, 2017).

www.europa.eu.int/pol/cons/overview_en. htm. (retrieved: Dec 21, 2017). 